\title{
DISSECTING US RECOVERIES
}

María oolores Gadea, Ana Gómez-Loscos. and Gabriel Perez-Quiros

Documentos de Trabajo. N. 1708

\section{BANCODE ESPANAA}

\author{
Eurosistema
}

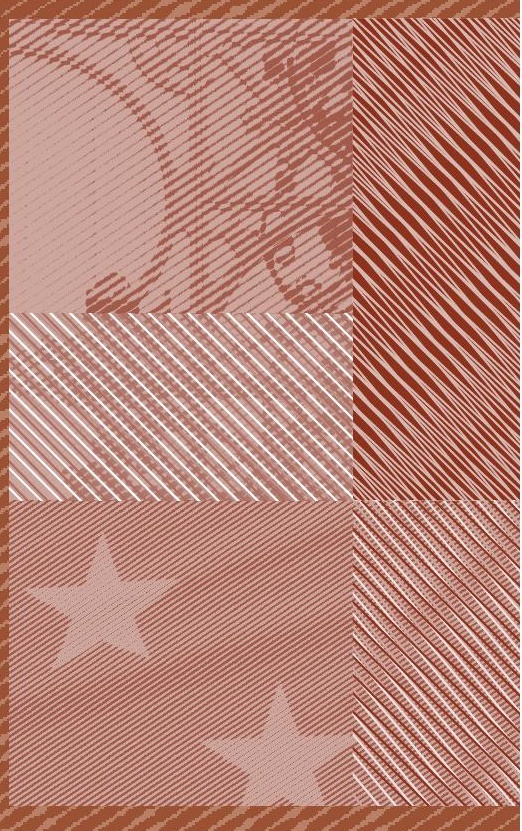


DISSECTING US RECOVERIES 
DISSECTING US RECOVERIES ${ }^{*}$

\section{María Dolores Gadea ${ }^{(* *)}$}

UNIVERSITY OF ZARAGOZA

Ana Gómez-Loscos ${ }^{(* \star)}$

BANCO DE ESPAÑA

Gabriel Pérez-Quirós ${ }^{(* * *)}$

BANCO DE ESPAÑA AND CEPR

(*) M. Dolores Gadea acknowledges financial support from the Ministerio de Ciencia y Tecnología under grants ECO2014-58991-C3-1-R and ECO2014-58991-C3-2-R. The views expressed in this paper are the responsibility of the authors and do not necessarily represent those of the Banco de España or the Eurosystem.

$\left.{ }^{(* *}\right)$ Department of Applied Economics, University of Zaragoza. Gran Vía, 4, 50005 Zaragoza (Spain). Tel: +34 976761 842, fax: +34 976761840 and e-mail: Igadea@unizar.es.

$\left.{ }^{\star \star \star *}\right)$ Banco de España, Alcalá, 48, 28014 Madrid (Spain). Tel: +34 91338 5817, fax: +34 915310059 and e-mail: agomezloscos@bde.es.

$\left(^{(\star \star *}\right)$ Banco de España, Alcalá, 48, 28014 Madrid (Spain). Tel: +34 91338 5333, fax: +34 915310059 and e-mail: gabriel.perez@bde.es. 
The Working Paper Series seeks to disseminate original research in economics and finance. All papers have been anonymously refereed. By publishing these papers, the Banco de España aims to contribute to economic analysis and, in particular, to knowledge of the Spanish economy and its international environment.

The opinions and analyses in the Working Paper Series are the responsibility of the authors and, therefore, do not necessarily coincide with those of the Banco de España or the Eurosystem.

The Banco de España disseminates its main reports and most of its publications via the Internet at the following website: http://www.bde.es.

Reproduction for educational and non-commercial purposes is permitted provided that the source is acknowledged.

(c) BANCO DE ESPAÑA, Madrid, 2017

ISSN: 1579-8666 (on line) 


\section{Abstract}

We propose a set of new quantitative measures to characterise more fully the features of economic recoveries. We apply these measures to post-war US expansions and use cluster analysis to determine that there are two different types of recoveries in recent US economic history, with most expansions before 1984 (Great Moderation) looking quite different from those after.

Keywords: business cycles, recoveries.

JEL classification: C22, E32. 


\section{Resumen}

En este trabajo, se propone un conjunto de medidas cuantitativas para capturar de forma más precisa las características de las recuperaciones económicas. Estas medidas se aplican a la economía de Estados Unidos, con datos posteriores a la Segunda Guerra Mundial. Un análisis clúster permite determinar la existencia de dos tipos diferentes de expansiones en Estados Unidos. Las recuperaciones anteriores a la Gran Moderación son claramente diferentes de las posteriores.

Palabras clave: ciclos económicos, recuperaciones.

Códigos JEL: C22, E32. 


\section{Introduction}

The slow pace of the recovery in the US after the Great Recession is a concern for economists and policymakers [see e.g. Fernald (2014), Summers (2014) and Fischer (2014)]. GDP growth has been lower than expected and downward revisions of projections have become usual. To have a deep knowledge of the path and nature of recoveries is of great interest, as this has consequences on long-run economic activity and job creation capacity. However, since the seminal paper of Harding and Pagan (2002), in which they dissect the business cycle phases, little effort has been made to develop new measures of the features of the recoveries. ${ }^{1}$ In this paper, we propose some new quantitative measures that enrich the analysis of the nature of recoveries. While the measures of Harding and Pagan (2002) are global and do not take into account the dynamics of recoveries, our measures allow to capture these dynamics, thus obtaining information on the different stages of recoveries. In particular, the early quarters of a recovery are key for an economy to recover the output lost during the recession. By means of a cluster analysis, we provide a comparison of different US recovery patterns, distinguishing a different behavior since the beginning of the Great Moderation (1984). ${ }^{2}$ The results are of fundamental interest for policymakers and for macroeconomists since they allow to capture the business cycle accurately. The new measures are easily reproducible for different countries and so are expected to be useful to compare stylized facts of different expansions and relate them with other economic variables.

\footnotetext{
${ }^{1}$ Bec et al. (2015) are an exception, but they work in a parametric framework.

${ }^{2}$ See Kim and Nelson (1999) and McConnell and Perez-Quiros (2000).
} 


\section{Measures}

Harding and Pagan (2002) propose four measures to examine the business cycle phases once turning points have been established by dating methods. These are (i) duration (in quarters), (ii) amplitude (which compares the log level of GDP at the turning points), (iii) cumulation (the cumulated gain or loss and consists of the sum of the amplitudes of each cyclical phase or total area described by the GDP in logs) and (iv) excess (the difference between the real area drawn by the path of the GDP growth in logs and the hypothetical triangle which would have formed with a linear growth rate throughout the whole phase). ${ }^{3}$ A positive Excess (concave path) means that the recovery starts with a high growth rate that subsequently slows down, whereas a negative Excess (convex path) is produced when the opposite happens. If the growth is uniform over the expansion period, then the Excess is zero. See Figure 1 for an illustration.

Excess would be a good measure to characterize the shape of expansions if they had a clear concave, convex or linear form but, in practice, cyclical phases are not always so stylized, as can be seen in Figure 2, so that this measure is not completely accurate.

To solve the difficulty in capturing the cycles depicted by the data, we propose a set of indicators that identify the evolution of the pattern of the expansions more comprehensively. If a recovery is quick (a V-shaped recovery), the effect of the recession is transitory and the economy continues its long-run growth trend but, if the improvement occurs slowly, it may have permanent effects on the economy (a L-shaped recovery). Specifically, we propose four

\footnotetext{
${ }^{3}$ Sichel (1993) suggests steepness and deepness and McQueen and Thorley (1993) introduce sharpness. However, these measures are calculated on filtered data, while ours are based on original data and therefore are invariant to future observations.
} 
types of measures: the first one captures the evolution over time of the shape of expansion. The second one captures the early stages of expansions, the third one focuses on the middle of the expansionary path. Finally, the fourth one shows the long-run consequences of the recoveries for future economic growth.

1. Time varying measures:

(a) Pointwise excess during the expansion $\left(E_{t}\right)$, being the excess at each point in time $t=1,2, \ldots \tau$...T defined as: ${ }^{4}$

$$
E_{t}(\tau)=\int_{0}^{\tau} f(t) d t-(\overline{0 \tau} * \overline{0 l(\tau)}) / 2
$$

(b) Acceleration of excesses: difference of pointwise excess between two consecutive periods $\left(\Delta E_{t}\right)$.

$$
\Delta E_{t}(\tau)=E_{t}(\tau)-E_{t}(\tau-1)
$$

2. Early stages measures:

(a) Early shape: the number of consecutive positive excesses at the beginning of the expansion or minus the number of consecutive negative excesses at the beginning of the expansion, in relation to the total duration of the expansion.

$$
\text { Early shape }=\frac{\tau^{E S}}{\overline{0 T}}
$$

where $\tau^{E S}$ is " $i$ " such that $E_{t}(i)>0 \forall i$ and " $-i$ " such that $E_{t}(i)<0$ $\forall i$.

\footnotetext{
${ }^{4}$ Notice that $E_{t}$ is computed until each $t$, that means $E_{t+i}$ can be positive despite the shape turns to convex in $t+i$.
} 
(b) Inshape: the number of consecutive periods with $E_{t}$ positive and $\Delta E_{t}$ positive or minus the number of consecutive periods with $E_{t}$ negative and $\Delta E_{t}$ negative. This measure captures changes in the shape, from concave to convex or from convex to concave.

$$
\text { Inshape }=\frac{\tau^{I}}{\overline{0 T}}
$$

where $\tau^{I}$ is " $i$ " such that $E_{t}(i)>0$ and $\Delta E_{t}(i)>0 \forall i$ and " $-i$ " so that $E_{t}(i)<0$ and $\Delta E_{t}(i)<0 \forall i$.

3. Middle of expansion measures:

(a) Half life: number of periods $\tau$ needed to obtain half of the cumulation, relative to the total duration. A value of $\frac{1}{\sqrt{2}}$ is equivalent to a triangular path. A higher value means that it has taken longer to recover the total area, while a smaller value corresponds to fast expansions.

$$
\text { Half life }=\frac{\tau^{H L}}{\overline{0 T}},
$$

so that $C\left(\tau^{H L}\right)=C(T) / 2$.

(b) Medium area: area obtained in the middle of the duration of the expansion in relation to the hypothetical triangle. We normalize the measure so that a value of 1 is equivalent to a linear path, a value below (above) 1 means a growth slower (quicker) than linear.

$$
\text { MediumArea }=4 \frac{\operatorname{Area}(\overline{0 T} / 2)}{\overline{0 T} * \overline{0 P} / 2}
$$


4. Long-run trend measures:

(a) Welfare: number of periods to recover the level of GDP previous to the recession in relation to the total duration of the expansion. Notice that this measure takes into account the depth of the recession.

$$
\text { Welfare }=\frac{\tau^{W}}{\overline{0 T}}
$$

where $\tau^{W}$, so that $f_{t}\left(\tau^{W}\right)=f_{t} P_{-1}$, where $P_{-1}$ is the peak of the previous expansion.

\section{Illustration: US recoveries}

We apply the new measures to establish the features of post-war US expansions and distinguish some patterns among them. We use the business cycle dating provided by the NBER to identify turning points. Since 1949, there have been 11 expansions in the US economy. We include the recovery after the Great Recession, although it has not finished yet.

We begin by computing the measures suggested by Harding and Pagan (2002) for each of the US expansions (Table 1). It seems that expansions after 1984 (Great Moderation) tend to be longer than previous expansions. Regarding excess, we observe that the shape of expansions deviates substantially from a triangular path in most cases. However, we do not identify any pattern of excesses over time.

These measures are very useful but do not take into account the dynamics of expansion, as they do not pay attention to the different stages of recoveries and, in particular, to the early quarters. 
The results of applying the new measures offer a more precise picture. The time-varying measures for each of the 11 expansions are shown in Figure 3. We observe that the Pointwise excess shows a very smooth path for expansions after 1984, with excesses being negative or very small. On the contrary, almost all the expansions prior to 1984 show positive $E_{t}$, which are very persistent, as displayed by Acceleration of excesses.

The scalar measures are shown in Table 2. Firstly, we present the measures that focus on the beginning of the phase. Before the Great Moderation, most of the expansions show positive excesses at the beginning, which continuously accelerate (Inshape). Early shape is 1 except for one expansion, whereas it is closer to 0 after 1984 . The 90 s expansion is always below the linear trend. Actually, it is a perfectly concave expansion (Early shape is -1 even though it is a 40 quarter expansion). ${ }^{5}$ The 2000 s expansion does not have a clear stylized form. It is convex at the beginning and then it turns into concave. ${ }^{6}$ From Table 1 we can only say that it is a concave expansion, thus missing important features in our analysis.

Secondly, we introduce the measures that give us information about the middle path of the phase. Results of Half life and Medium area show that recoveries before the Great Moderation were quick, whereas those after it are slower.

Thirdly, we compute Welfare and obtain that after the 90s and the 2000s expansions, the GDP recovered its previous level very quickly; while after the Great Recession, it took 9 quarters to recover the GDP level of the previous peak due both to a very deep recession and a slow recovery.

\footnotetext{
${ }^{5}$ The size of these negative excesses increases during almost its whole duration and it only gains momentum close to the end (Inshape).

${ }^{6}$ It has just three positive pointwise excesses at the beginning and then, it decelerates. Early shape represents just 0.1 of its total duration.
} 
In order to identify common patterns from our proposed scalar measures, we carry out a cluster analysis, using the $K$-means procedure. ${ }^{7}$ We find that expansions can be classified into 3 clusters. As shown in panel A of Figure 4, the first group comprises expansions up to 1984; while the second includes the last three expansions, as well as that of $1975 .^{8}$ Finally, the third cluster consists of a single expansion, that of $1980 .^{9}$ The main difference between the two first clusters lies in the behavior during the first quarters of the recoveries. ${ }^{10}$ The early stages of an expansion are known as the high growth recovery phase and its disappearance is recognized as one of the features characterizing the Great Moderation. ${ }^{11}$

Panel B of Figure 4 shows the cluster analysis using the standard Harding and Pagan (2002) measures. We identify no clear lesson from this classification that allows to relate each group with some macroeconomic events. On the contrary, the new measures clearly contribute to understanding expansion features behind the Great Moderation.

\footnotetext{
${ }^{7}$ This method creates a single level of clusters and assigns each expansion to a specific cluster. The algorithm finds a partition in which expansions within each cluster are as close to each other as possible and as far from the expansions in other clusters as possible. Each cluster is defined by its centroid, which is the point at which the sum of the distances from all the objects in the cluster is minimized. The number of groups has been selected considering the Silhouette value that indicates that the object is well matched to its own cluster and poorly matched to neighboring clusters.

${ }^{8}$ The dynamic of the early stages of the 1975 expansion is more similar to those of expansions after the beginning of the Great Moderation.

${ }^{9}$ It has the quickest cumulated recovery in the middle of expansion (Half life and Medium area), although it took several quarters to recover the GDP level previous to the recession (Welfare).

${ }^{10}$ In the first type of expansions, the averages of Early shape, Inshape, Half life, Medium area and Welfare are $0.67,6.5,0.61,1.35,0.11$, respectively. In the second type, the figures are $-0.26,-7.50,0.67,1.05$ and 0.40 , respectively.

${ }^{11}$ See Gadea et al. (2014), Camacho et al. (2011), and Gali et al. (2012).
} 


\section{Conclusions}

We propose a set of measures to identify the features of expansions. We observe an increase in precision with respect to the very valuable measures proposed by Harding and Pagan (2002), as we consider the dynamics of recoveries. We find that the path of expansions is different in terms of evolution over time, speed of recoveries and welfare consequences. According to the new measures, we identify that expansions before and after the beginning of the Great Moderation (1984) are clearly different. 


\section{References}

Bec, F., Bouabdallah, O., and Ferrara, L. (2015). "Comparing the shape of recoveries: France, the UK and the US." Economic Modelling, 44(C), 327-334.

Camacho, M., Perez Quiros, G., and Rodriguez Mendizabal, H. (2011). "High-growth recoveries, inventories and the Great Moderation." Journal of Economic Dynamics and Control, 35(8), 1322-1339.

Fernald, J. (2014). "Productivity and potential output before, during, and after the Great Recession." NBER Macroeconomics Annual 2014, 29, 1-51.

Fischer, S. (2014). "The Great Recession: Moving Ahead." Conference Sponsored by the Swedish Ministry of Finance, Stockholm, Sweden, August 11. https://www.federalreserve.gov/newsevents/speech/fischer20140811a.pdf.

Gadea, M. D., Gomez-Loscos, A., and Perez-Quiros, G. (2014). "The Two Greatest. Great Recession vs. Great Moderation." CEPR Discussion Paper Series, 10092.

Gali, J., Smets, F., and Wouters, R. (2012). "Slow Recoveries: A Structural Interpretation." Journal of Money, Credit and Banking, 44, 9-30.

Harding, D., and Pagan, A. (2002). "Dissecting the cycle: a methodological investigation." Journal of Monetary Economics, 49(2), 365-381.

Kim, C.-J., and Nelson, C. R. (1999). "Has The U.S. Economy Become More Stable? A Bayesian Approach Based On A Markov-Switching Model Of The Business Cycle." The Review of Economics and Statistics, 81(4), 608-616.

McConnell, M. M., and Perez-Quiros, G. (2000). "Output Fluctuations in the United States: What Has Changed since the Early 1980's?" American Economic Review, 90(5), 1464-1476.

McQueen, G., and Thorley, S. (1993). "Asymmetric Business Cycle Turning Points." Journal of Monetary Economics, 31, 341-362.

Sichel, D. E. (1993). "Business Cycle Asymmetry." Economic Inquiry, 31, 224-236.

Summers, L. H. (2014). "U.S. Economic Prospects: Secular Stagnation, Hysteresis, and the Zero Lower Bound." Business Economics, 49(2), 65-73. 


\section{Tables}

Table 1: Harding and Pagan measures

\begin{tabular}{l|cccc}
\hline \hline Measure & Duration & Amplitude & Cumulation & Excess \\
\hline 1949.4-1953.2 & 14.00 & 0.26 & 2.18 & 0.38 \\
$1954.2-1957.3$ & 13.00 & 0.13 & 1.06 & 0.23 \\
$1958.2-1960.2$ & 8.00 & 0.11 & 0.57 & 0.13 \\
$1961.1-1969.4$ & 35.00 & 0.42 & 8.32 & 0.99 \\
$1970.4-1973.4$ & 12.00 & 0.15 & 0.98 & 0.09 \\
$1975.1-1980.1$ & 20.00 & 0.21 & 2.39 & 0.30 \\
$1980.3-1981.3$ & 4.00 & 0.04 & 0.11 & 0.02 \\
$1982.4-1990.3$ & 31.00 & 0.32 & 6.01 & 0.98 \\
1991.1-2001.1 & 40.00 & 0.35 & 6.92 & -0.18 \\
2001.4-2007.4 & 24.00 & 0.17 & 2.12 & 0.14 \\
2009.2-2016.2 & 28.00 & 0.14 & 2.09 & 0.08 \\
\hline \hline
\end{tabular}

Table 2: New measures

\begin{tabular}{l|ccccc}
\hline \hline Measure & Early shape & Inshape & Half life & Medium area & Welfare \\
\hline $1949.4-1953.2$ & 1.00 & 13.00 & 0.57 & 1.61 & 0.07 \\
$1954.2-1957.3$ & 1.00 & 12.00 & 0.56 & 1.72 & 0.15 \\
$1958.2-1960.2$ & 1.00 & 7.00 & 0.53 & 1.63 & 0.25 \\
$1961.1-1969.4$ & 1.00 & 34.00 & 0.66 & 1.19 & 0.03 \\
$1970.4-1973.4$ & 1.00 & 3.00 & 0.62 & 1.09 & 0.08 \\
$1975.1-1980.1$ & -0.10 & -1.00 & 0.65 & 1.18 & 0.15 \\
$1980.3-1981.3$ & 1.00 & 3.00 & 0.37 & 1.76 & 0.50 \\
$1982.4-1990.3$ & 1.00 & 30.00 & 0.64 & 1.45 & 0.06 \\
$1991.1-2001.1$ & -1.00 & -30.00 & 0.70 & 0.88 & 0.07 \\
2001.4-2007.4 & 0.13 & 2.00 & 0.66 & 1.03 & 0.00 \\
2009.2-2016.2 & -0.07 & -1.00 & 0.67 & 1.09 & 0.32 \\
\hline \hline
\end{tabular}




\section{$6 \quad$ Figures}

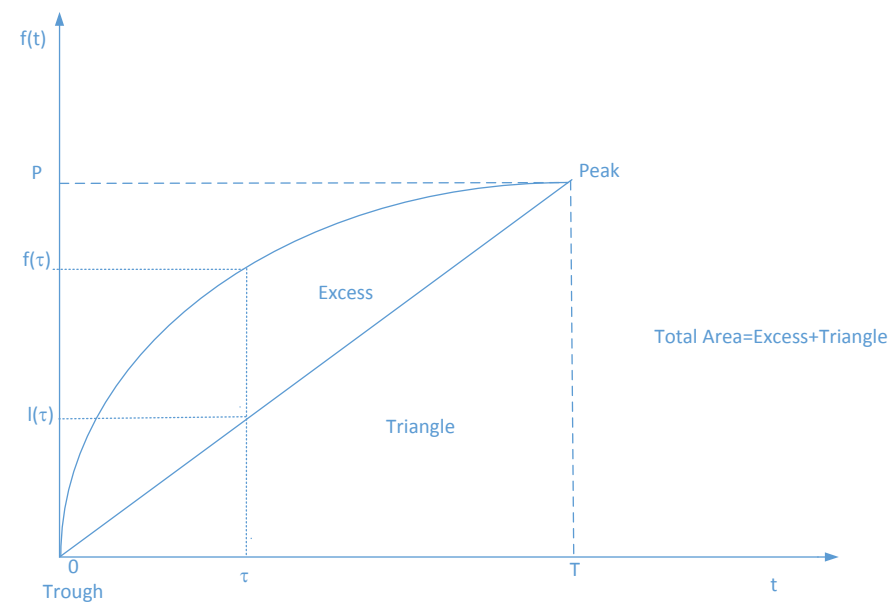

(a) Concave

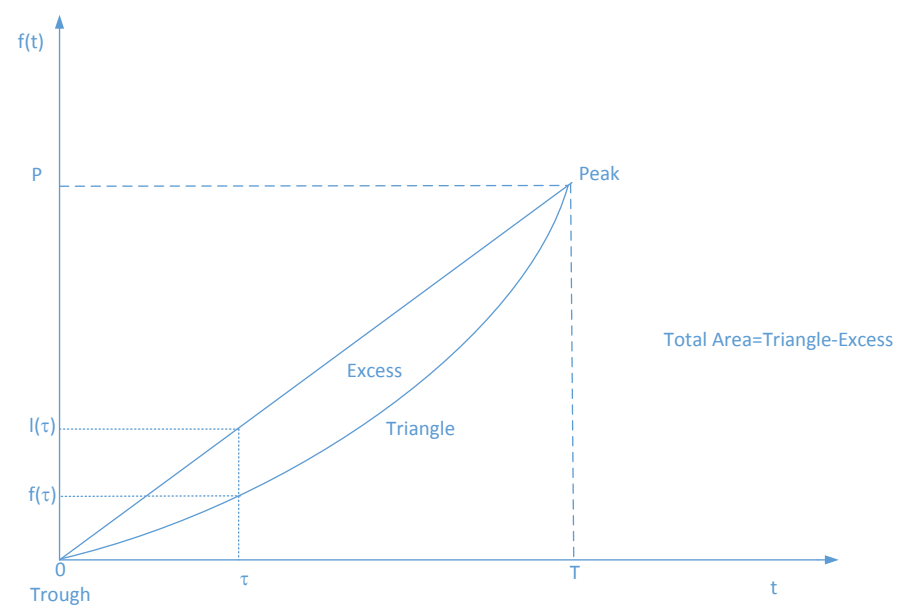

(b) Convex

Figure 1: Shape of recoveries

Notes: Duration: $\overline{0 T} ;$ Amplitude: $\overline{0 P} ;$ Cumulation: $\int_{0}^{T} f(t) d t$; and Excess: $\int_{0}^{T} f(t) d t-(\overline{0 T} *$ $\overline{0 P}) / 2$. 

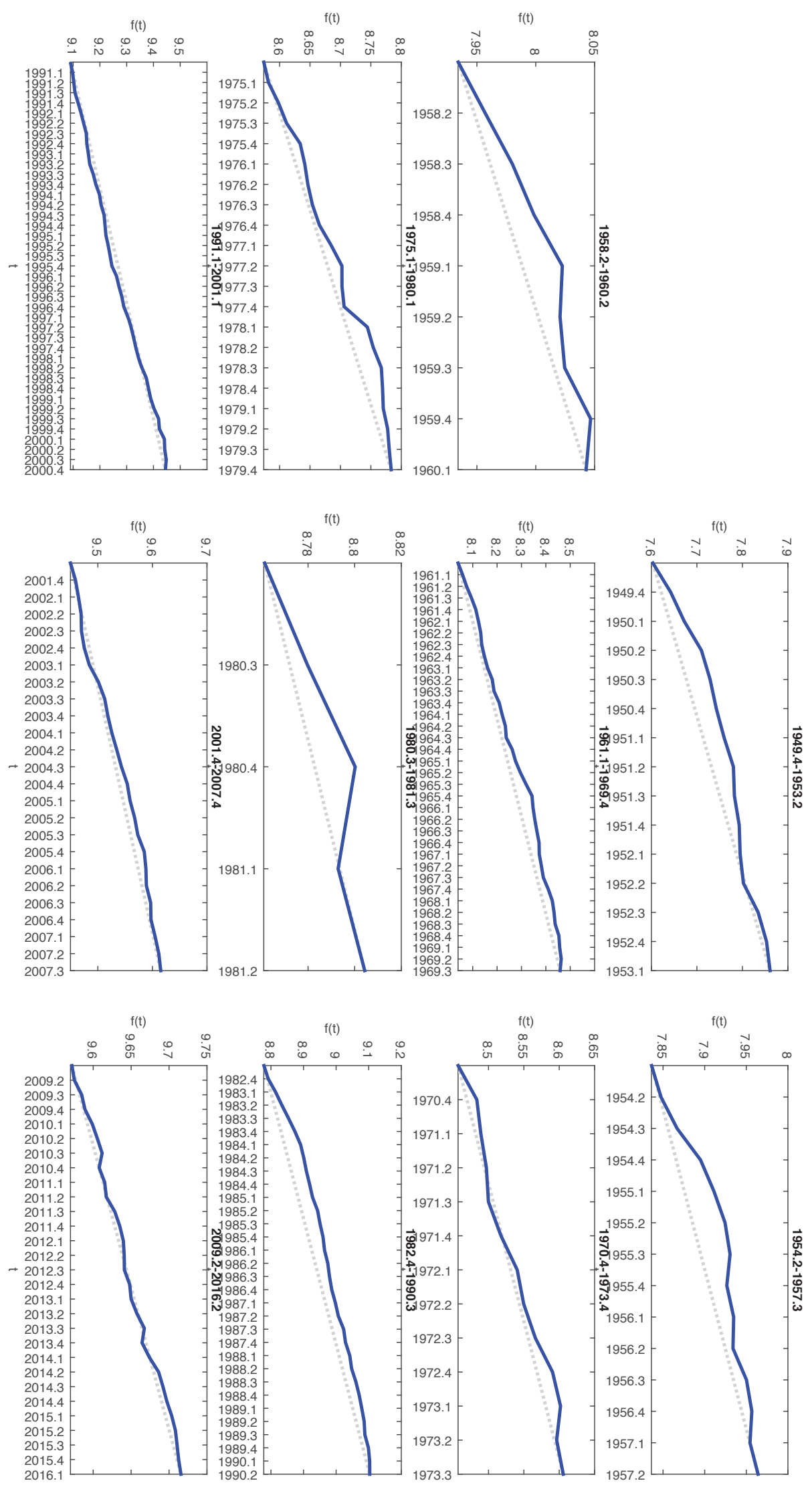

Figure 2: Shapes of US expansions

Note: This figure displays the evolution of log real GDP from through to peak for each of the postwar US expansions and a line representing linear growth between throughs and peaks. 

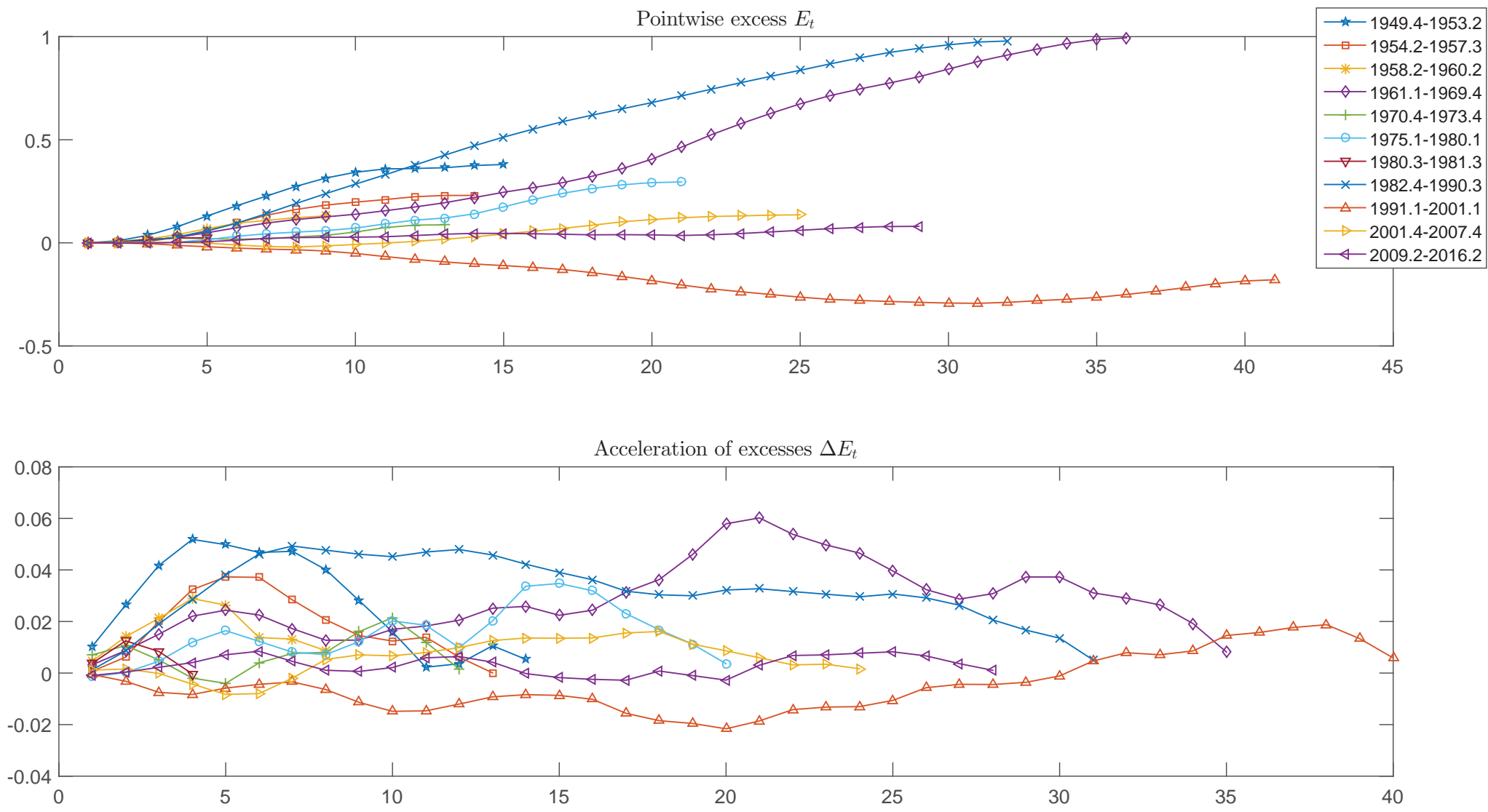

Figure 3: Time varying measures 


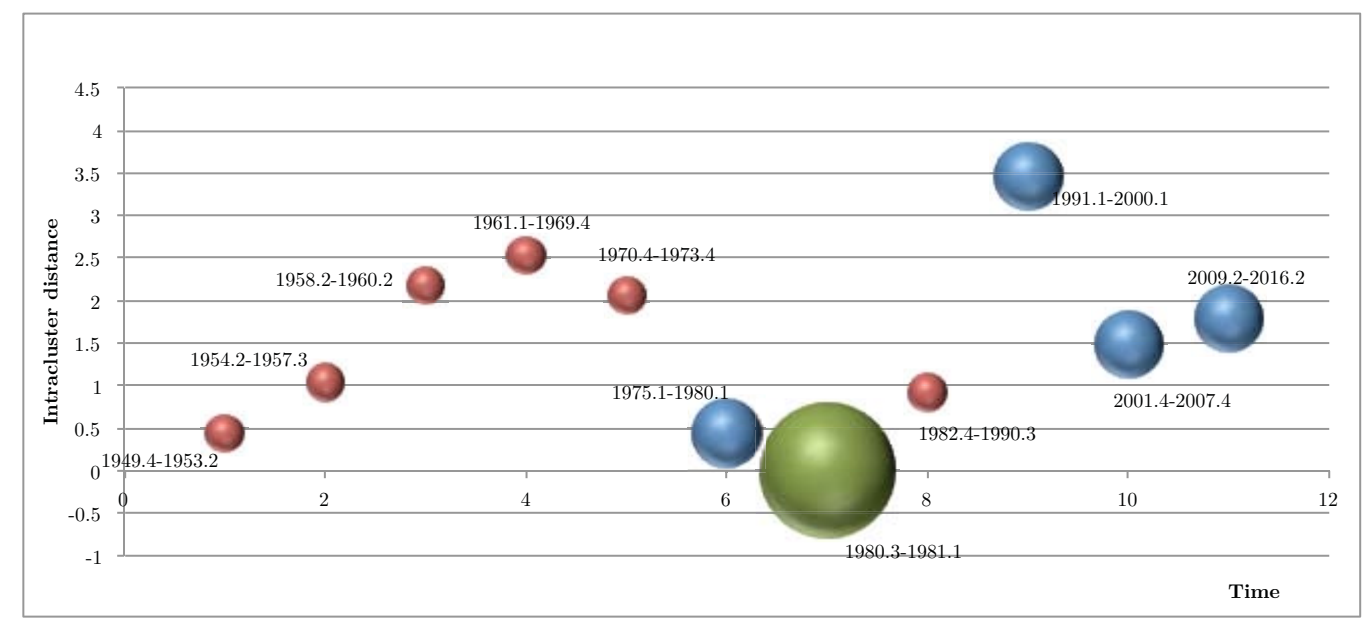

(a) New measures

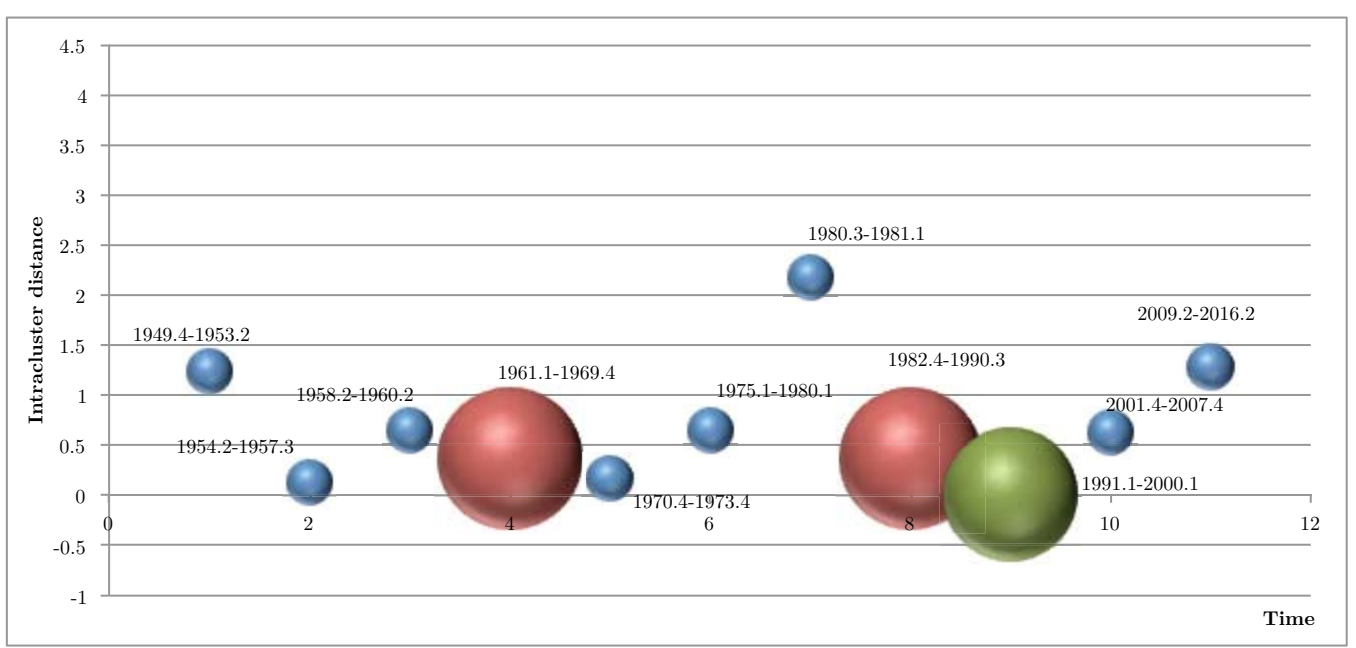

(b) Harding and Pagan measures

Figure 4: Clusters of US recoveries by measures

Note: Expansions in chronological order are displayed over the $\mathrm{X}$ axis. Intra-cluster distance is represented over the $\mathrm{Y}$ axis. The size of the ball represents the size of the corresponding centroid of each cluster, which is built from the Euclidean distance of all the characteristics included in the analysis. 


\title{
BANCO DE ESPAÑA PUBLICATIONS
}

\author{
WORKING PAPERS
}

1530 CRISTINA FERNÁNDEZ and PILAR GARCÍA PEREA: The impact of the euro on euro area GDP per capita.

1531 IRMA ALONSO ÁLVAREZ: Institutional drivers of capital flows.

1532 PAUL EHLING, MICHAEL GALLMEYER, CHRISTIAN HEYERDAHL-LARSEN and PHILIPP ILLEDITSCH: Disagreement about inflation and the yield curve.

1533 GALO NUÑO and BENJAMIN MOLL: Controlling a distribution of heterogeneous agents.

1534 TITO BOERI and JUAN F. JIMENO: The unbearable divergence of unemployment in Europe.

1535 OLYMPIA BOVER: Measuring expectations from household surveys: new results on subjective probabilities of future house prices.

1536 CRISTINA FERNÁNDEZ, AITOR LACUESTA, JOSÉ MANUEL MONTERO and ALBERTO URTASUN: Heterogeneity of markups at the firm level and changes during the great recession: the case of Spain.

1537 MIGUEL SARMIENTO and JORGE E. GALÁN: The influence of risk-taking on bank efficiency: evidence from Colombia.

1538 ISABEL ARGIMÓN, MICHEL DIETSCH and ÁNGEL ESTRADA: Prudential filters, portfolio composition and capital ratios in European banks.

1539 MARIA M. CAMPOS, DOMENICO DEPALO, EVANGELIA PAPAPETROU, JAVIER J. PÉREZ and ROBERTO RAMOS: Understanding the public sector pay gap.

1540 ÓSCAR ARCE, SAMUEL HURTADO and CARLOS THOMAS: Policy spillovers and synergies in a monetary union.

1601 CHRISTIAN CASTRO, ÁNGEL ESTRADA and JORGE MARTÍNEZ: The countercyclical capital buffer in Spain: an analysis of key guiding indicators.

1602 TRINO-MANUEL ÑíGUEZ and JAVIER PEROTE: Multivariate moments expansion density: application of the dynamic equicorrelation model.

1603 ALBERTO FUERTES and JOSÉ MARÍA SERENA: How firms borrow in international bond markets: securities regulation and market segmentation.

1604 ENRIQUE ALBEROLA, IVÁN KATARYNIUK, ÁNGEL MELGUIZO and RENÉ OROZCO: Fiscal policy and the cycle in Latin America: the role of financing conditions and fiscal rules.

1605 ANA LAMO, ENRIQUE MORAL-BENITO and JAVIER J. PÉREZ: Does slack influence public and private labour market interactions?

1606 FRUCTUOSO BORRALLO, IGNACIO HERNANDO and JAVIER VALLÉS: The effects of US unconventional monetary policies in Latin America.

1607 VINCENZO MERELLA and DANIEL SANTABÁRBARA: Do the rich (really) consume higher-quality goods? Evidence from international trade data.

1608 CARMEN BROTO and MATÍAS LAMAS: Measuring market liquidity in US fixed income markets: a new synthetic indicator.

1609 MANUEL GARCÍA-SANTANA, ENRIQUE MORAL-BENITO, JOSEP PIJOAN-MAS and ROBERTO RAMOS: Growing like Spain: 1995-2007.

1610 MIGUEL GARCÍA-POSADA and RAQUEL VEGAS: Las reformas de la Ley Concursal durante la Gran Recesión.

1611 LUNA AZAHARA ROMO GONZÁLEZ: The drivers of European banks' US dollar debt issuance: opportunistic funding in times of crisis?

1612 CELESTINO GIRÓN, MARTA MORANO, ENRIQUE M. QUILIS, DANIEL SANTABÁRBARA and CARLOS TORREGROSA Modelling interest payments for macroeconomic assessment.

1613 ENRIQUE MORAL-BENITO: Growing by learning: firm-level evidence on the size-productivity nexus.

1614 JAIME MARTÍNEZ-MARTÍN: Breaking down world trade elasticities: a panel ECM approach.

1615 ALESSANDRO GALESI and OMAR RACHEDI: Structural transformation, services deepening, and the transmission of monetary policy.

1616 BING XU, ADRIAN VAN RIXTEL and HONGLIN WANG: Do banks extract informational rents through collateral?

1617 MIHÁLY TAMÁS BORSI: Credit contractions and unemployment. 
1618 MIHÁLY TAMÁS BORSI: Fiscal multipliers across the credit cycle.

1619 GABRIELE FIORENTINI, ALESSANDRO GALESI and ENRIQUE SENTANA: A spectral EM algorithm for dynamic factor models.

1620 FRANCISCO MARTÍ and JAVIER J. PÉREZ: Spanish public finances through the financial crisis.

1621 ADRIAN VAN RIXTEL, LUNA ROMO GONZÁLEZ and JING YANG: The determinants of long-term debt issuance by European banks: evidence of two crises.

1622 JAVIER ANDRÉS, ÓSCAR ARCE and CARLOS THOMAS: When fiscal consolidation meets private deleveraging.

1623 CARLOS SANZ: The effect of electoral systems on voter turnout: evidence from a natural experiment.

1624 GALO NUÑO and CARLOS THOMAS: Optimal monetary policy with heterogeneous agents.

1625 MARÍA DOLORES GADEA, ANA GÓMEZ-LOSCOS and ANTONIO MONTAÑÉS: Oil price and economic growth: a long story?

1626 PAUL DE GRAUWE and EDDIE GERBA: Stock market cycles and supply side dynamics: two worlds, one vision?

1627 RICARDO GIMENO and EVA ORTEGA: The evolution of inflation expectations in euro area markets.

1628 SUSANA PÁRRAGA RODRÍGUEZ: The dynamic effect of public expenditure shocks in the United States.

1629 SUSANA PÁRRAGA RODRÍGUEZ: The aggregate effects of government incometransfer shocks - EU evidence.

1630 JUAN S. MORA-SANGUINETTI, MARTA MARTÍNEZ-MATUTE and MIGUEL GARCÍA-POSADA: Credit, crisis and contract enforcement: evidence from the Spanish loan market.

1631 PABLO BURRIEL and ALESSANDRO GALESI: Uncovering the heterogeneous effects of ECB unconventional monetary policies across euro area countries.

1632 MAR DELGADO TÉLLEZ, VÍCTOR D. LLEDÓ and JAVIER J. PÉREZ: On the determinants of fiscal non-compliance: an empirical analysis of Spain's regions.

1633 OMAR RACHEDI: Portfolio rebalancing and asset pricing with heterogeneous inattention.

1634 JUAN DE LUCIO, RAÚL MÍNGUEZ, ASIER MINONDO and FRANCISCO REQUENA: The variation of export prices across and within firms.

1635 JUAN FRANCISCO JIMENO, AITOR LACUESTA, MARTA MARTÍNEZ-MATUTE and ERNESTO VILLANUEVA: Education, labour market experience and cognitive skills: evidence from PIAAC.

1701 JAVIER ANDRÉS, JAVIER J. PÉREZ and JUAN A. ROJAS: Implicit public debt thresholds: an empirical exercise for the case of Spain.

1702 LUIS J. ÁLVAREZ: Business cycle estimation with high-pass and band-pass local polynomial regression.

1703 ENRIQUE MORAL-BENITO, PAUL ALLISON and RICHARD WILLIAMS: Dynamic panel data modelling using maximum likelihood: an alternative to Arellano-Bond.

1704 MIKEL BEDAYO: Creating associations as a substitute for direct bank credit. Evidence from Belgium.

1705 MARÍA DOLORES GADEA-RIVAS, ANA GÓMEZ-LOSCOS and DANILO LEIVA-LEON: The evolution of regional economic interlinkages in Europe.

1706 ESTEBAN GARCÍA-MIRALLES: The crucial role of social welfare criteria for optimal inheritance taxation.

1707 MÓNICA CORREA-LÓPEZ and RAFAEL DOMÉNECH: Service regulations, input prices and export volumes: evidence from a panel of manufacturing firms.

1708 MARÍA DOLORES GADEA, ANA GÓMEZ-LOSCOS and GABRIEL PÉREZ-QUIRÓS: Dissecting US recoveries.

BANCODEESPAÑA

Eurosistema
Unidad de Servicios Auxiliares

Alcalá, 48 - 28014 Madrid

E-mail: publicaciones@bde.es www.bde.es 